\title{
Listening Strategies Use in the Internet Learning Environment by Non-English Major College Students: A Comparison between Male and Female Listeners
}

\author{
Xiu-hua Ma (Corresponding author) \\ Department of College Foreign Language Teaching, Taishan University \\ Taian 271021, Shandong, China \\ E-mail: maxiuhuahl@126.com
}

Received: July 4, 2014 Accepted: July 18, 2014 Published: June 24, 2015

doi:10.5296/ijch.v2i1.7886 URL: http://dx.doi.org/10.5296/ijch.v2i1.7886

\begin{abstract}
Based on the researches of listening strategies at home and abroad, this study tries to explore the gender's effect on the use of listening strategy under the internet autonomous learning environment and finds the differences as well as the similarities in the use of listening strategies. The results have some implications for teachers. English teachers should take the factors of gender into account in the course of strategy training, especially cultivating male students' use of the social/affective strategies.
\end{abstract}

Keywords: Listening strategies, Gender, Differences and similarities

\section{Research Background}

Listening comprehension, as a widely used language skill in daily life, has been playing an important part in language learning and daily communication. With the implementation of College English Curriculum Requirements in 2007 and the reform of CET-4 and CET-6 (College English Test-Band Four and Six) issued by the Ministry of Education in China, the cultivation of college students' listening and speaking abilities in foreign language learning has become an important task for Chinese college foreign language teachers.

With the development of information technology, Computers have been widely used in language learning and teaching. The Ministry of Education in China strongly advocates that web-based autonomous learning should be integrated into college English courses, especially college English listening and speaking. In recent years, most colleges and universities try to change their teaching models with the help of computers. So autonomous learning has been adopted by many colleges and universities to create an authentic language learning 
environment, which has brought positive influence on students' foreign language learning. However, due to various reasons in different aspects, the actual use of the Internet in the foreign language learning still has a long way to go.

\section{Literature Review}

\subsection{Listening Strategies}

Listening strategies refers to techniques, approaches or actions that students take in their listening process to help their listening comprehension. In the past several decades, the use of language learning strategies has been one of the hot topics in foreign language learning research. O'Malley et al. (1985), Oxford (1990), Nunan have done a lot of research on language learning strategies. Nunan (1991) thinks learning strategies are the mental and communicative procedures that learners use in order to learn and use language. Oxford (1990) thinks "Strategies are especially important for language learning, because they are tools for active, self-directed involvement, which is essential for developing communicative competence". On the basis of language learning strategies developed by O'Malley and Chamot (1990), which has gained considerable acceptability, listening strategies can also be classified into three categories: meta-cognitive strategies, cognitive strategies and social/affective strategies. Meta-cognitive strategies employed in listening comprehension include planning, selective attention, directed attention, self-management, self-monitoring, self-evaluation and problem identification. Cognitive strategies in listening comprehension include prediction, repetition, resourcing, translation, note-taking, auditory representation, key word, transfer, inferencing, selective listening, material selection and elaboration. Social/affective strategies in listening comprehension include interest-raising, self-reinforcement, lowering anxiety, cooperation and clarifying.

\subsection{Studies on Listening Strategies}

Compared with the investigations on learning strategies in reading and speaking, the number of studies on listening strategies is relatively small. Defillipis (1980), selected the second-term students who study French at the beginning level as the participants. The participants were divided into two groups. He found that there are more similarities than differences of learning strategies use between skillful listeners and unskillful listeners. Murphy (1985) studied the listening strategy use by university students who study English as a second language in 1985 . He found that more skilled listeners use a wider variety of different strategies than unskilled listeners. O'Malley and Chamot (1990) have found that there is a great significant difference of the learning strategies between the effective and ineffective listeners. Vandergrift (2003) conducted an investigation of listening strategy use by seventh-grade students of French and discovered that the more skilled listeners used more meta-cognitive strategies. Wang (2002) conducted a survey about non-English majors' use of listening strategies in China and found significant difference of different level students in the use of meta-cognitive strategies and cognitive strategies in the establishment of profound comprehension. In the above-mentioned studies, there is a great difference between the subjects with different language proficiency in the listening comprehension strategy use. 


\subsection{Studies on Listening Strategies under Internet-based Autonomous Environment}

Internet-based autonomous listening is a new form of listening learning and teaching. In the internet-based autonomous listening environment, students learn to improve their listening abilities on their own with the guidance of their teachers through internet. Many empirical studies have been studied about the autonomous listening learning under the internet-based autonomous environment. With the development of college English teaching reform, this topic has caused more and more college foreign language teachers and language researchers' attention.

Brett (1996) conducted a study of the affective domain of multimedia for listening skills and learning result with the use of multimedia and found that learners' performance showed more effective comprehension while using multimedia than audio or video plus pen and paper. Lin (2006) made a research on teaching English listening in a web-based self-access learning environment by investigating non-English majors and found that the web-based self-access environment can encourage students to use learning strategies to some degree. Xiao and Zuo (2006) found there are great differences between good listeners and poor listeners in the "autonomous learning class". Zhu Jing and Sun Yina (2012) conducted a survey in the way of questionnaires and interviews and found that there exists positive correlation between learning motivation and meta-cognitive strategies for non-English major students under the internet environment. Zhu Xiaoshen and Deng Juntao (2011) carried out an investigation about the web-based autonomous English listening learning situation of wenzhou University students and found that listening strategy training can help improve the students' autonomous learning ability.

From the above literature review, it can be seen that language researchers and teachers both at home and abroad have made a lot of studies about foreign language listening learning and teaching, many of which are related to listening strategies. However, few studies about the listening strategies mention whether there exists any gender difference in the use of listening strategies in the web-based learning environment. Recently various web-based language learning systems are provided by many foreign language presses in China. In present study, the author conducts a study about the gender's use of listening strategies in the web-based learning environment by comparing male and female listeners, hoping to offer some implications for the future language listening teaching and learning.

\section{Research Design}

\subsection{Participants}

In this study, 326 participants, including 150 (46\%) males and $176(53 \%)$ females, are the second-year non-English majors from two different departments (Chinese department and math department) in Taishan University in Shandong Province, whose native language is Chinese. They are under the same English teacher's instruction. Their ages range from 17 to 22 and they have their English classes in the internet language labs, where Students can make their own proper plans, select suitable exercises and communicate with peers and teachers through the Internet. 
Table 1. Information of the participants

\begin{tabular}{|l|l|l|l|}
\hline \multirow{2}{*}{ Gender } & male & 150 & $46 \%$ \\
\cline { 2 - 4 } & female & 176 & $53 \%$ \\
\hline Total number & 326 & \\
\hline
\end{tabular}

\subsection{Instruments-The Listening Strategy Questionnaire}

Compared with other investigating methods, Questionnaire is one of the most common research methods. The questionnaire is mainly to study the learners' employment of listening strategies in listening comprehension.

The questionnaire was designed in Chinese so as to avoid the possibility of participants' misunderstanding the strategy items. It contains two parts: the personal background information of the participants, including age, gender, major, and the language learning strategies employed by the participants in the English listening process. The questionnaire consists of 23 items, each item is rated on a five-point Likert Scale ranging from 1 (strongly disagree) to 5 (strongly agree), which are arranged in the order of meta-cognitive strategies (6 items), cognitive strategies (12 items) and social/affective strategies (5 items) as table 2.

Table 2. The questionnaire items of listening strategy and the reliability coefficients

\begin{tabular}{|c|c|c|c|}
\hline Listening strategy & Subdivisions & Item number & Alpha Value \\
\hline \multirow{6}{*}{$\begin{array}{l}\text { Meta-cognitive } \\
\text { strategies }\end{array}$} & Planning & 1 & .7626 \\
\hline & Directed attention & 2 & .7798 \\
\hline & Selective attention & 3 & .7835 \\
\hline & Monitoring & 4 & .7352 \\
\hline & Self-evaluation & 5 & .7541 \\
\hline & Self-management & 6 & .6875 \\
\hline \multirow{8}{*}{ Cognitive strategies } & Prediction & 7 & .7526 \\
\hline & Note-taking & 8 & .7723 \\
\hline & Translation & 9 & .7546 \\
\hline & Elaboration & 10 & .7857 \\
\hline & Key word & 11 & .7462 \\
\hline & Inferencing & 12 & .7289 \\
\hline & Transfer & 13 & .8013 \\
\hline & Auditory representation & 14 & .7648 \\
\hline
\end{tabular}




\begin{tabular}{|l|l|l|l|}
\hline \multirow{5}{*}{} & Selective listening & 15 & .6078 \\
\cline { 2 - 4 } & Resourcing & 16 & .7853 \\
\cline { 2 - 4 } & Material selection & 17 & .7862 \\
\cline { 2 - 4 } Strategies & Repetition & 18 & .8216 \\
\hline \multirow{5}{*}{$\begin{array}{l}\text { Social/affective } \\
\end{array}$} & Self-encouragement & 19 & .7557 \\
\cline { 2 - 5 } & Interest-raising & 20 & .7362 \\
\cline { 2 - 4 } & Lowering anxiety & 21 & .7263 \\
\cline { 2 - 4 } & Cooperation & 22 & .6952 \\
\cline { 2 - 4 } & Clarifying & 23 & .7263 \\
\hline
\end{tabular}

The above table shows clearly the major categories of listening strategy, the dimensions and the number of items under each category in the questionnaire. The internal consistency of strategy variables checked by item-total correlations show that all the items are internally consistent ( all the alpha. values $>0.5$ ).

\subsection{Procedure}

In order to make the study accurate, before the investigation, the teacher makes it clear to the participant students that the questionnaire would have no influence on their academic achievement and honest responses would be very important for teachers' study. It took the participants about 15 minutes to complete. After the completion, the questionnaires were collected at once and returned to the researcher for the data analysis. Then the collected data of the questionnaire were keyed into the computer and were analyzed by the software SPSS 17.0. The descriptive statistics was employed to find the means and the standard derivation which indicate the overall use frequency of listening strategies by male and female college non-English majors and independent-sample T-tests were used to find out the effect of gender on strategy use.

\section{Statistical Description of Listening Strategies Used by Male and Female Students}

In order to find gender's influence on the use of listening strategy use, the independent-sample T-test is used and the results are shown in the following tables. 
4.1 Overall Use of the Listening Strategies by Male and Female Students

Table 3. T-test of the overall use of all categories of male and female listeners

\begin{tabular}{|c|c|c|c|c|c|c|}
\hline \multirow{2}{*}{ Category } & \multicolumn{2}{|l|}{ Male } & \multicolumn{2}{|c|}{ Female } & \multirow{2}{*}{ T-value } & \multirow{2}{*}{ Sig.(2-tailed) } \\
\hline & M & S.D & M & S.D & & \\
\hline Meta-cognitive strategies & 2.86 & .814 & 3.02 & .792 & -1.160 & .255 \\
\hline Cognitive strategies & 3.28 & .288 & 3.27 & .242 & .518 & .705 \\
\hline Social/affective strategies & 2.76 & .772 & 3.54 & .661 & -7.415 & $* .000$ \\
\hline Overall & 2.97 & .572 & 3.26 & .237 & -2.435 & .0192 \\
\hline
\end{tabular}

$* \mathrm{p} \leq 0.01$

From the above table, it can be shown that female students (mean=3.26) use listening strategies more often than male ones (mean=2.97) overall under the internet learning environment, but there is no great difference between them. These findings are in line with the study results of Goh \& Kwah's (1997) and Green \& Oxford's (1995).

Among the three major listening strategies, female students use meta-cognitive strategies and social/affective strategies more often than males (meta-cognitive strategies: 3.02>2.86, social/affective strategies: $3.54>2.76$ ). In the three major types, there are no significant gender differences in students' use of cognitive strategies and meta-cognitive strategies in this study, but the difference in social/affective strategy use is obviously significant (mean $=3.54>2.76, \mathrm{p}=.000 \leq 0.01$ ).

Table 3 shows that the male and female students employ much the same cognitive strategies (mean=3.28, 3.27) and meta-cognitive strategies (mean=2.86>3.02) in their listening activities, which may attribute to the fact that both the males and females have the similar language learning experience and they are more or less the same in their cognitive development. Table 3 also shows that females use social/affective strategies more often than males. Oxford (1995:40) thought that there exist various differences in the learning styles between males and females. (wen, 2004) points out that gender usually can not influence foreign language learning strategy directly, but it often influence learning strategy use indirectly through learning styles. Other researchers' studies show that females have a higher desire to please and gain approval through good grades and social behavior than males (Mansnerus, 1989; Oxford et al., 1988). So females' more frequent use of strategies could have something to do with their higher desire for good grades and others' approval.

\subsection{Comparison of the Meta-Cognitive Strategies'Use between Male and Female Listeners}

In order to find the detailed gender's effect on the use of meta-cognitive strategies, the 
independent-sample T-test is employed and the results are shown in the following table.

Table 4. T-test of the use of meta-cognitive strategies by males and females

\begin{tabular}{|c|c|c|c|c|c|c|}
\hline \multirow{2}{*}{ Sub-categories } & \multicolumn{2}{|c|}{ Male } & \multicolumn{2}{|c|}{ Female } & \multirow{2}{*}{ T-value } & \multirow{2}{*}{ Sig.(2-tailed) } \\
\hline & $M$ & S.D & M & S.D & & \\
\hline Planning & 3.02 & .584 & 3.27 & 631 & -1.752 & .084 \\
\hline Directed attention & 3.01 & .635 & 3.03 & .742 & .045 & .964 \\
\hline Selective attention & 2.84 & .636 & 2.96 & .770 & -.956 & .342 \\
\hline Monitoring & 2.74 & .632 & 3.16 & 663 & -2.882 & $* .003$ \\
\hline Self-evaluation & 2.78 & .602 & 3.08 & 646 & -2.102 & .038 \\
\hline Self-management & 2.77 & .613 & 3.06 & .757 & -1.793 & .076 \\
\hline
\end{tabular}

$$
* \mathrm{p} \leq 0.01
$$

According to the above table, among the six sub-categories, there is no significant difference between them except monitoring, although females use the strategies of planning, selective attention, self-evaluation, self-management more often than those of males, while males use the strategies of directed attention, monitoring more often than those of females. In these sub-categories, the most significant difference exists in the use of monitoring strategies. It shows that females can control their listening activity better than males in the listening activities, which may attribute to their different learning styles.

\subsection{Comparison of the Cognitive Strategies'Use between Male and Female Listeners}

Table 5. T-test of the use of cognitive strategies by male and female listeners

\begin{tabular}{|c|c|c|c|c|c|c|}
\hline \multirow{2}{*}{ Sub-categories } & \multicolumn{2}{|l|}{ Male } & \multicolumn{2}{|c|}{ Female } & \multirow{2}{*}{ T-value } & \multirow{2}{*}{ Sig.(2-tailed) } \\
\hline & $M$ & S.D & $M$ & S.D & & \\
\hline Prediction & 3.62 & .763 & 3.64 & .735 & .051 & .958 \\
\hline Note-taking & 3.01 & 828 & 3.06 & 865 & -.375 & .730 \\
\hline Translation & 3.71 & 916 & 3.32 & .743 & 2.046 & .041 \\
\hline Elaboration & 3.42 & .751 & 3.07 & .886 & 1.802 & .080 \\
\hline Key word & 3.31 & 841 & 3.22 & 837 & .563 & .579 \\
\hline Inferencing & 3.21 & .763 & 3.27 & .835 & -.821 & .423 \\
\hline Transfer & 3.02 & 831 & 3.02 & .732 & .000 & 1.000 \\
\hline Auditory representation & 2.54 & .793 & 3.04 & .786 & -2.734 & $* .008$ \\
\hline
\end{tabular}




\begin{tabular}{|l|l|l|l|l|l|l|}
\hline Selective listening & 3.71 & .921 & 3.42 & .687 & 1.628 & .109 \\
\hline Resourcing & 3.06 & .826 & 3.01 & .576 & .379 & .710 \\
\hline Material selection & 3.65 & .779 & 3.52 & .832 & .676 & .506 \\
\hline Repetition & 3.23 & .485 & 3.40 & .467 & -1.489 & .138 \\
\hline
\end{tabular}

$$
*_{p} \leq 0.01
$$

It can be seen from Table 3 that the use frequency of cognitive strategies of males $($ mean=3.28) is very close to the one of females (mean=3.27). As is shown in Table 4, some means of the subcategories use of cognitive strategies by males are higher than those by females, that is, translation (mean $=3.71>3.32$ ), transfer (mean=3.31>3.22), resourcing (mean=3.06 $>3.01$ ), selective listening (mean=3.71 $>3.42$ ), key words (mean=3.31 $>3.22$ ), elaboration (mean $=3.42>3.07$ ) and material selection (mean $=3.65>3.52$ ). While other means of the cognitive strategies use by males are lower than those by females, including note-taking (mean=3.01<3.06), Key word (mean=3.31<3.22), auditory representation $($ mean $=2.54<3.04)$, and repetition $($ mean $=3.23<3.40)$. The others are close to each other. Although there are some differences between the means of the use of subcategories of cognitive strategies of males and females, these differences are not statistically significant except the auditory representation. Prediction ( mean $=3.62,3.64$ ) and material selection ( mean $=3.65,3.52$ ) are most frequently used by both males and females, which are at the high level (3.5- 4.4). The results are partly due to their listening practice for examination in their middle school and in line with that of the use of cognitive strategies of all the subjects. The significant difference in auditory representation strategy proves that males do not pay much attention to their speaking practice. They may seldom think of practicing speaking and listening at the same time.

From the above analysis, we can know that the gender differences in cognitive strategy use are not significant except the auditory representation. Some strategies are favored by males, while some others are favored by females. According to Table 4, males tend to use translation, selective listening and material selection. They are good at using previous knowledge to help their listening comprehension and select proper listening materials to improve their listening comprehension. While female students have a tendency to repeat what they have heard to practice their speaking. They attach much more importance to their speaking practice than males. 
4.4 Comparison of the Social/Affective Strategies' Use between Male and Female Listeners

Table 6. T-test of the use of social/affective strategies by male and female listeners

\begin{tabular}{|c|c|c|c|c|c|c|}
\hline \multirow{2}{*}{ Sub-category } & \multicolumn{2}{|l|}{ Male } & \multicolumn{2}{|c|}{ Female } & \multirow{2}{*}{ T-value } & \multirow{2}{*}{ Sig.(2-tailed) } \\
\hline & $M$ & S.D & $M$ & S.D & & \\
\hline Self-reinforcement & 2.68 & .864 & 2.96 & .765 & -1.489 & .139 \\
\hline Interest-raising & 2.73 & .656 & 3.33 & .782 & -3.613 & $* .001$ \\
\hline Lowering anxiety & 2.98 & .707 & 3.73 & .806 & -4.305 & $* .000$ \\
\hline Cooperation & 2.77 & .502 & 3.38 & .568 & -4.827 & $* .000$ \\
\hline Clarifying & 2.79 & .622 & 3.28 & .822 & -2.924 & $* .005$ \\
\hline
\end{tabular}

$* \mathrm{p} \leq 0.01$

From the above Table 5, we can find that there is great significant difference between genders in the use of most sub-categories of social/affective strategies except the self- reinforcement $(\mathrm{p}=0.139>0.01)$. That is to say, most females can control their listening activities and try to relax themselves (interest-raising mean $=3.32>2.72$, lowering anxiety mean $=3.72>2.96$ ) when they are afraid in their listening activities. What's more, females like working with their peers (cooperation mean $=3.29>2.60$ ) or asking their teachers to solve some problems and get feedback from them (clarifying mean $=3.29>2.78$ ) in their listening tasks. These great gender differences in strategy use may be attributed to the gender's different attitudes and motivation towards English learning. Their different personality and learning styles may also be accounted for great gender differences in strategy use.

\section{Implications}

\subsection{Strategies Used by Male and Female Learners in College English Learning}

From the above investigation, females use listening strategies more often than males in generally in the internet autonomous listening environment, but there is no great difference between them. There is no significant difference in the use frequency of meta-cognitive strategy and cognitive strategies between males and females among the three major types of listening strategies. However, the frequency of social/affective strategy use by female listeners are much higher than those of males and the difference is very significant.

In the subcategories with significant differences in their use, female learners are better at monitoring their listening activity and using auditory representation strategy than males, Which means females can control their learning better and pay more attention to their speaking practice. There is significant difference between genders in the use of all the sub-categories of social/affective strategies except the self- reinforcement. Female listeners generally use the social/affective strategies more frequently than male listeners. It implies that females are better than males at controlling their learning emotions and cooperating with others in their listening performance. 


\subsection{Pedagogical Implications}

From the above investigation and analysis, it is evident that there are some significant differences as well as similarity between male listeners and female listeners in the use of listening strategies under the web-based autonomous language listening learning environment, which can give college foreign language teachers some pedagogical implications in their daily teaching.

Firstly, college foreign language teachers should take gender into consideration when they train learners listening strategies. First, teachers should try to know learners' strategy use at the beginning of the course. Then teachers should help learners to know their listening strategy use and encourage them to try to use various listening strategies. Third, college foreign language teachers should improve male listeners' awareness of using the social/affective strategies in their listening performance. Male listeners should be encouraged to attend various English listening and speaking activities. Teachers should help male listeners learn how to reduce their anxiety, cooperate with others and become more confident. Secondly, college foreign language teachers should try to provide various listening materials and create a variety of suitable activities for both males and females. In this way, students may improve their listening comprehension and make great progress as soon as possible.

\section{References}

Brett, P. A. (1997). Comparative Study of the Effects of the Use of Multimedia on Listening Comprehension. $\quad$ Retrieved July 11, 2010, from http://faculty.ksu.edu.sa/yousif/Research\%20Papers/The\%20effects\%20of\%20using\%20mult imedia.pdf

Defillipis, D. A. (1980). A Study of the Listening Strategy Used by the Skillful and Unskillful College French Students in Aural Comprehension Tasks. Diss. University of Pittsburgh.

Goh, C. M., \& Kwah, P. (1997). Chinese ESL Students' Learning Strategies: a Look at Frequency, Efficiency and Gender. Hong Kong Journal of Applied Linguistics, 2, 39-53.

Green, J, M., \& Oxford, R. L. (1995). A Closer Look at Learning Strategies, L2 Proficiency and Gender. TESOL Quarterly, 29(2), 261-296. http://dx.doi.org/10.2307/3587625

Murphy, J. M. (1985). An Investigation into the Listening Strategies of ESL College Students. Paper presented at the 19th Annual TESOL Convention, New York.

Nunan, D. (1991). Language Teaching Methodolog. Hertford shire: Prentice Hall International (UK) Ltd.

O’Malley, J. M., \& Chamot, A. U. (1990). Learning Strategies in Second Language Acquisition. Cambridge: Cambridge University Press. http://dx.doi.org/10.1017/CBO9781139524490

O’Malley, J. M., Chamot, A. U., Stewner-Manzanares, G., Russo, R. P., \& Kupper, L. (1985). Learning Strategy Applications with Students of English as a Second Language. TESOL Quarterly, 19(3), 557-584. http://dx.doi.org/10.2307/3586278 


\section{Macrothink}

International Journal of Culture and History

ISSN 2332-5518 2015, Vol. 2, No. 1

Oxford, R. (1990). Language Learning Strategies: What Every Teacher Should Know. New York: Newbury House.

Oxford, R. (1995). Gender Differerces in Language Learning Styles: What Do They Mean? In J. M. Reid (Ed.), Learning Styles in the ESL/EFL Classroom. Beijing; Foreign Language Teaching and Research Press.

Oxford, R., Nyikos, M., \& Ehrman, M. (1988). Reflections on Sex Differences in Use of Language Learning Strategies. Foreign Language Annals, 21(4), 321-329. http://dx.doi.org/10.1111/j.1944-9720.1988.tb01076.x

Vanergrift, L. (2003). Orchestrating Strategy Use: Toward a Model of the Skilled Second Language Listener. Language Learning, 53(3), 463-496. http://dx.doi.org/10.1111/1467-9922.00232

\section{Copyright Disclaimer}

Copyright for this article is retained by the author(s), with first publication rights granted to the journal.

This is an open-access article distributed under the terms and conditions of the Creative Commons Attribution license (http://creativecommons.org/licenses/by/3.0/). 